\title{
DESKRIPSI TINGKAH LAKU TANGKASI ( Tarsius Spectrum ) SAAT MEMASUKI DI LUBANG SARANG POHON DI CAGAR ALAM TANGKOKO
}

\author{
Jemi Urulamo, H.J. Kiroh, Manopo Hendrik, J.R.Buyung \\ Fakultas Peternakan Universitas Sam Ratulangi, Manado 95115
}

\begin{abstract}
ABSTRAK
Tarsius yang ada di Cagar Alam Tangkoko batuangus banyak mendiami rongga-rongga pohon ataupun pada tumpukan akar.Sarang Tarsius merupakan tempat yang dianggap aman dari serangan predator.Penelitian ini bertujuan untuk mendapatkan data mengenai beberapa tingkah laku Tarsius yang muncul saat Tarsius beraktifitas disekitar sarang pohon di Cagar Alam Tangkoko. Untuk mengatahui besarnya persentase masing -masing tingkah laku Tarsius yang di tunjukan di pagi hari, siang dan sore hari. Variabel yang diamati adalah beberapa tingkah laku yang muncul diantaranya.Tingkah laku grooming ,Tingkah laku beristirahat, Tingkah laku mencari tempat berteduh, Tingkah laku bermain, Data yang diperoleh dianalisis dan disajikan secara Deskriptif, yaitu menguraikan dan menjelaskan mengenai gambaran umum dari hasil pengamatan secara lansung,hasil penilitian menujukan bahwa Tangkasi lebih banyak melakukan grooming pada waktu pagi dengan persentase $37,15 \%$. siang hari dengan persentase $31,19 \%$ sore hari dengan persentase $31,19 \%$. Tingkah laku beristirahat Tangkasi paling banyak terjadi saat siang hari yaitu 38,70\%.Pada malam hari dengan persentase $32,25 \%$, sore hari dengan persentase
\end{abstract}

29,03\%.Tingkah laku berteduh lebih banyak beraktifitas dipagi hari dengan persentase $38,07 \%$ dan pada waktu siang denga persentase $33,02 \%$.Sedangkan pada sore hari dengan persentase 28,89 \%Tingkah laku bermain hampir merata ditiap waktu. Pada waktu pagi Tangkasi bermain setelah selesai mencari makan dengan persentase 30, $18 \%$ dan pada waktu siang hari dengan persentase $32,88 \%$ dan paling banyak pada waktu sore dengan persentase $37,38 \%$.

Kata Kunci : Tingkah Laku, Tangkasi ( Tarsius spectrum ), Tangkoko

\section{ABSTRACT}

DESCRIPTION OF TANGKASI BEHAVIOR (Tarsius Spectrum) WHEN ENTERING THE HOLE NEST TREE IN TANGKOKO NATURE RESERVE. Tarsier in Tangkoko Nature Reserve Batuangus many inhabit cavities in trees or root piles. Tarsier nest is a place that is safe from predators. This study aims to obtain data regarding some behavior that appears when Tarsier Tarsius activity around the nest tree at Tangkoko Nature Reserve. To determine the percentage of respective behavior that tarsiers in the show in the morning, afternoon and evening. The variables measured were some behaviors that 
arise between them. Grooming behavior, resting behavior, seeking shelter behavior, play behavior, data were analyzed and presented in a descriptive, which describes and explains the general description of the results of direct observations, the results showed that more Tangkasi doing grooming on morning with a percentage of $37.15 \%$. during the day with a percentage of $31.19 \%$ early evening with a percentage of $31.19 \%$. Tangkasi resting behavior is most prevalent during the day ie $38.70 \%$. At night with a percentage of $32.25 \%$, in the afternoon with $29.03 \%$ percentage. Sheltering behavior more activity in the morning with a percentage of $38.07 \%$ and the time of day with the percentage of $33.02 \%$. While in the afternoon with a percentage of $28.89 \%$ behavior played almost evenly in each time. On the morning after finished foraging Tangkasi playing with percentage of $30,18 \%$, and the percentage of time during the day with $32.88 \%$ and a maximum in the late afternoon with a percentage of $37.38 \%$.

Keywords: Behavior Tangkasi (Tarsius spectrum)

\section{PENDAHULUAN}

Sulawesi Utara memiliki keanekaragaman jenis fauna endemik, salah satunya Tarsius spectrum jenis primata, yang sangat menarik untuk dipelajari mulai dari habitat, spesies, jenis pakan alami, sebaran, daerah jelajah dan tingkah lakunya dialam bebas. Tarsius spectrum termasuk satwa primata kecil, berekor panjang, melompat dari pohon ke pohon secara vertical dan merupakan hewan insektivora serta karnivora yaitu pemakan jenis serangga seperti belalang cicak ngengat,ulat, dan hewan melata lainya.

Tarsius yang ada Cagar Alam Tangkoko batu angus banyak mendiami rongga-rongga pohon ataupun pada tumpukan akar.Sarang Tarsius merupakan tempat yang dianggap aman dari serangan predator dan juga sebagai tempatnsumber makanan yang dapat memenuhi kebutuhan Tarsius, serta dijadikan tempat bernaung dan beristirahat .Tarsius hidup berkelompok disetiap sarang dan biasanya dalam satu sarangterdapat 3-7 ekor Tarsius.

Pelestarian Tarsius penting untuk peningkatan populasi dan ini dapat dilakukan dengan metode penangkaran baik dihabitat asli (in-situ) maupun diluar habitat aslinya (ex-situ). Penangkaran Tarsius diluar habitat aslinya (ex-situ) diperlukan pemahaman dasar perilaku secara komprehensif. Menurut Thomaszewka al ( 1991),bahwa dengan penguasaan tingkah laku satwa secara lengkap akan mempermudah tatalaksana pemiliharaan dan peningkatan produksi satwa.Di Cagar Alam Tangkoko banyak terjadi kunjungan para wisatawan lokal maupun mancanegara yang tertarik dengan keberadaan dari Tarsius Spctrum . 
Bahkan ada sarang pohon tertentu yang dijadikan lokasi tempat khusus bagi para pengunjung untuk dapat melihat dan terkadang member makanan seperti belalang, cicak, atau jenis makanan insektifora atau karnivora yang masih hidup. Kebiasaan - kebiasaan ini diduga ikut mengubah polah aktifitas sebagai satwa nocturnal ( hewan malam) yang bayak beraktifitas di malam hari, Untuk membuktikan apakah pengaruh kujungan dan polah kebiasaan member makanan ini dapat memunculkan kebiasaan waktu beraktifitas dari Tarsius dengan tampilan tingkah laku yang yang ditunjukan baru saat beraktifitas di sekitar sarang pohon, maka perlu dilakukan suatu kajian ilmiah.

Informasi tingkah laku Tarsius spectrum saat beraktifitas disekitar sarang pohon belum pernah diteliti padahal pemahaman beberapa tingkah laku satwa merupakan dasar ilmiah yang dapat digunakan untuk mengembangbiakan satwa baik semi in- situ maupun ex-situ dalam kaitan menujang upaya konservasi agar satwa endemik ini tetap meningkat populasinya. Untuk itulah telah dilakukan suatu penelitian dasar tentang beberapa tingkah laku Tarsius spectrum saat beraktifitas disekitarsarang pohon yang ada di cagar alam tangkoko dimana hasil penelitian ini dapat dijadikan rekomendasi ilmiah yang sangat bermanfaat demi menunjang kehidupan satwa liar yang khas di sulawesi utara.

\section{MATERI DAN METODE PENELITIAN}

Penelitian dilaksanakan di Cagar Alam Tangkoko Batu Angus Kota Bitung Sulawesi Utara. Penelitian dilakukan selama dua bulan dengan rincian satu bulan pra penelitian (orientasi lapagan) dan satu bulan pengambilan data. Penelitian ini dilaksanakan pada tanggal 1 April sampai dengan 31 mei tahun 2013. Materi penelitian yang digunakan adalah, Tarsius spectrum yang berada dalam satu kelompok yaitu 7 ekor, dilokasi sarang pohon di cagar Alam Tangkoko Batu angus Bitung.

\section{Peralatan Penelitian :}

- Pita untuk penandaan lokasi sarang pohon yang akan dijadikan lokasi pengamatan di lapangan.

- Jam untuk mengukur waktu pengamatan, tingkah laku Tarsius spectrum selama beraktifitas di sarang pohon.

- Penerangan (Senter) untuk membantu melihat tingkah laku Tarsius spectrum selama 
beraktifitas di sore menjelang malam hari.

- Kamera untuk mengambil gambar tingkah laku yang teramati.

- Alat Tulis Menulis untuk mencatat data-data dalam penelitian.

\section{Metode Penelitian}

a. Orientasi lapangan

Sebelum pengambilan datapenelitian dilakukan orientasi lapangan selama kurang lebih satu bulan untuk megetahui situasi serta kondisi lapangan area sarang yang merupakan home base (tempat tinggal), Tarsius selama beraktifitas dan jumlah populasi tertinggi dalam sarangnya.

b. Membuat line ( penanda garis) Tarsius, yang telah diketahui jumlah populasi tertinggi dalam sarang pohon, untuk mempermudah pengamatan lapangan.

c. Data dikumpulkan dengan menggunakan metode ad libitum sampling (Alison, 1995) dimana pengambilan data dilakukan dengan cara melihat mengamati secara lansung dan mencatat informasi tentang beberapa tingkah laku yang muncul selama penelitian. d. Diuraikan dalam suatu bentuk Tabel ethogram dengan pengamatan dilakukan pada pagi jam ( 05.00 8.00) dan siang hari ( $10.00-13.00)$ serta sore hari ( $15.00-17.00)$, data yang dikumpulkan dilakukan selama kurang lebih tiga puluh hari. Teknik pengambilan data dilakukan dengan bantuan video kamera yang diletakan disekitar pohon yang dijadikan sarang oleh Tangkasi (Tarsius spectrum) dan pengamatan dilakukan pada suatu lobang sarang pohon, yang didiami 5-7 ekor Tarsius sebagai populasi tertinggi.

\section{Variabel Penelitian}

Variabel yang diamati adalah beberapa tingkah laku yang muncul diantaranya.

- Tingkah laku grooming diukur dengan melihat aktifitas pembersihan bulu seperti menjilat bagian - bagian tubuh, menggosok - gosok bagian tubuh ketempat lain ; membalik -balikkan tubuh serta mengibas-ibas tubuh.

- Tingkah laku beristirahat diukur dengan melihat aktifitas seperti mengecilkan.bola matanya sambil mengerutkan daun telinga dalam posisi bergelantungan atau duduk sambil menekukkan kedua kaki depan sehingga tubuh terlihat 
semakin kecil dan ini dilakukan dalam satu kelompok sehingga membentuk tumpukkan kelompok yang rapat dan berhimpitan.

- Tingkah laku mencari tempat berteduh diukur dengan melihat aktifitas yang ditunjukan dari seekor jantan dewasa sebagai pemimpin dalam mengamati-amati sangkar sebelum masuk kedalamnya sambil mengisyaratkan dengan selengkingan suara yang khas barulah mereka masuk secara berurutan.

- Tingkah laku bermain diukur dari aktifitas yang ditunjukan dalam satu kelompok seperti gerakan menyentakkan kedua kaki dan tangan dan sesekali menendang kekiri dan kekanan bahkan kebelakang.

\section{Analisis data}

Data informasi yang diperoleh dianalisis dan disajikan sebagai berikut.

1. Deskriptif, yaitu menguraikan dan menjelaskan mengenai gambaran umum dari hasil pengamatan secara lansung.

2. Presentase yaitu untuk mengambarkan proporsi aktifitas tingkah laku menurut jumlah frekuensi dan lama waktu. Perhitungan persentase frekuensi tingkah laku Tarsius spectrum menggunakan.

Rumus :

$\%$ Tingkah laku $=\frac{\text { frekuensi tingkah laku }}{\text { Total frekuensi tingkah laku }} \times 100 \%$

3. Histogram, yaitu untuk mengambarkan hubungan antara parameter -parameter yang diukur atau diamati dari penyajian, (Hadinoto, 1993).

\section{HASIL DAN PEMBAHASAN}

Secara umum tingkah laku Tangkasi ( Tarsius spectrum) yang teramati selama penelitian di Cagar alam Tangkoko saat beraktifitas di sekitar sarang pohon adalah tingkah laku grooming, tingkah laku beristrahat, tingkah laku mencari tempat berteduh, dan tingkah laku bermain. Tingkah laku yang lain tidak terlihat selama penelitian. Hal ini mengartikan bahwa di saat Tarsius bersiap - siap memasuki sarang lubang pohon maka hanya perilaku inilah yang dia tunjukan sebagai bentuk ekspresi akibat faktor-faktor yang mempengaruhinya seperti tingkah lakunya terkait dengan fungsi retina mata 


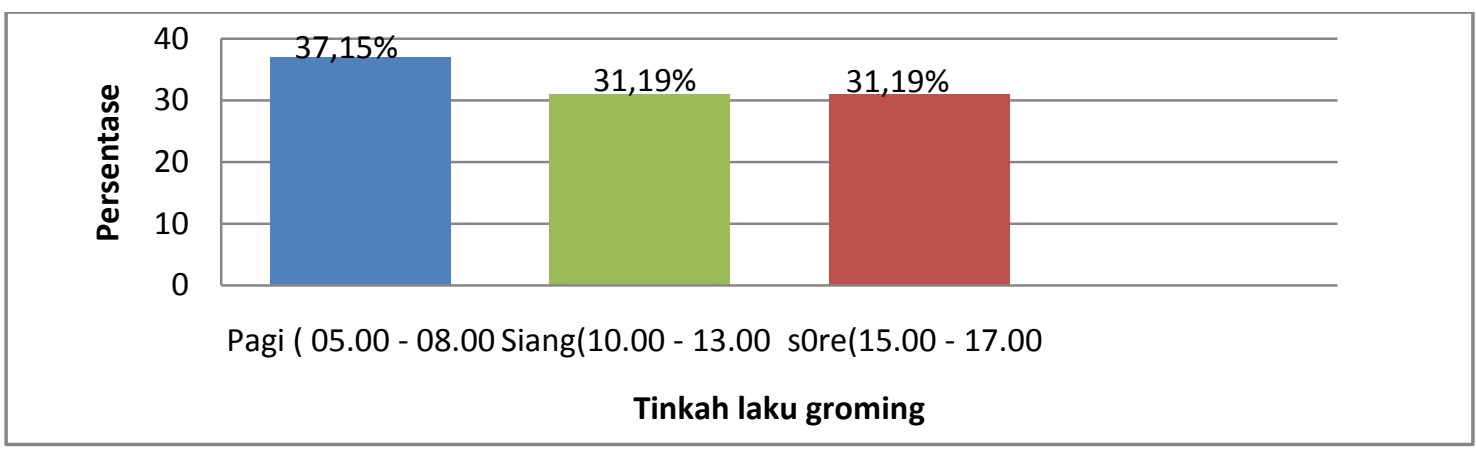

Gambar 1. Persentase tingkah laku grooming Tangkasi( Tarsius spectrum.)

sebagai satwa (nocturnal ) yang tidak begitu berperan pada siang hari konsekwensinya bahwa satwa nocturnal ini akan membatasi aktifitas perilakunya di alam bebas di siang hari.

\section{Tingkah Laku Grooming}

Tingkah laku grooming atau membersihkan diri atau bulu menurut Suratmo (1970), adalah sebuah aktifitas primata yang sifatnya umum. Saling membersihkan bulu merupakan suatu mekanisme aplikasi yang penting dan aktivitas digunakan untuk memperkuat jaringan di antara mereka. Hasil penelitian didapati bahwa tingkah laku grooming Tangkasi paling banyak terjadi pada pagi dan sore hari. Hal ini menunjukan bahwa Tangkasi lebih suka membersihkan diri saat memasuki lubang sarang dan saat akan keluar sarang dimana mereka memasuki sarang pohon secara berkelompok antara 2 sampai 6 ekor sehingga sangat memungkinkan terjadi tingkah laku sosial seperti tingkah laku grooming. Adapun tingkah laku grooming yang ditunjukan saat memasuki dan keluar dari lubang sarang diawali dengan Tangkasi duduk bersebelahan satu dengan yang lain dan melakukan grooming ,dengan cara menjilat-jilat bagian kaki, tangan, dada, perut, telinga, dan kadangkadang menggosok -gosok mulut. Kegiatan ini dilakukan sebagai bentuk kasih sayang induk pada anaknya. Sedangkan tingkah laku grooming Tangkasi dewasa mengarah pada bentuk membersihkan diri ini mengartikan suatu kegiatan mencari kotoran tubuh sendiri atau dilakukan invidu lain saat bangun tidur saat tubuhnya basa dengan cara menjilat - jilat tubuh dan menggosok gosok suatu tempat. Persentase Tingkah laku grooming Tangkasi terlihat pada Gambar 1.

Tangkasi lebih banyak melakukan grooming pada waktu pagi dengan persentase $37,15 \%$, siang hari persentase $31,19 \%$, dan sore hari dengan persentase $31,19 \%$. Semua ini membuktikan bahwa Tarsius lebih banyak beraktifitas pada malam hari (nocturnal) memulai 


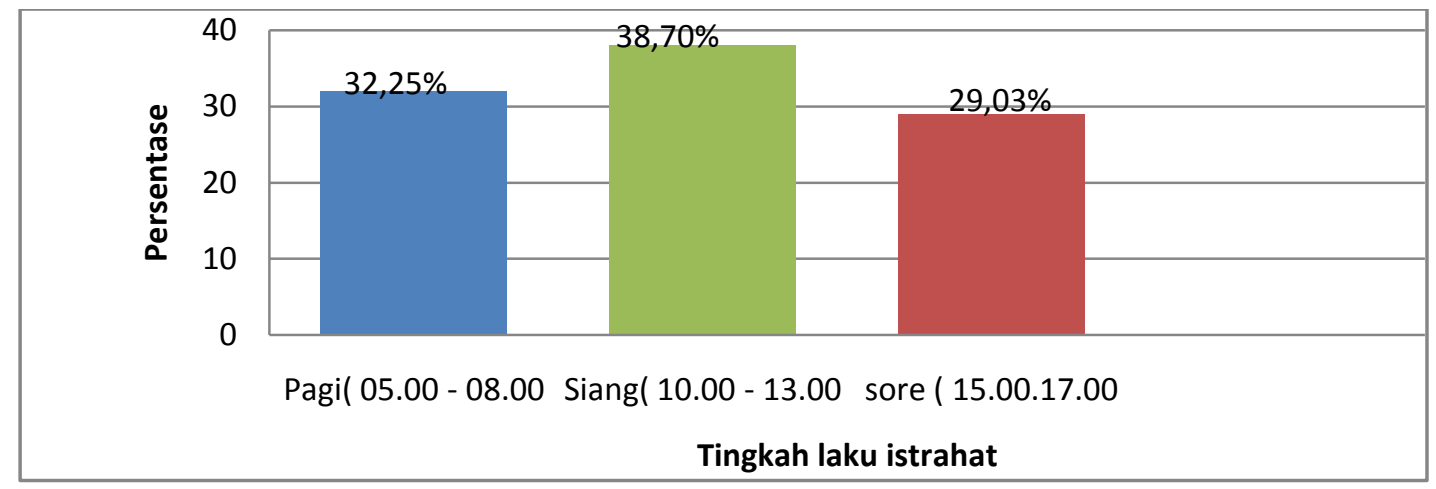

Gambar 2. Persentase tingkah laku beristirahat Tangkasi (Tarsius spectrum)

aktifitasnya dan mengakhiri aktifitasnya dengan melakukan grooming. Tangkasi berada di Cagar Alam Tangkoko lebih banyak melakukan grooming di dalam lubang sarang dan ranting pohon

\section{Tingkah Laku Beristirahat}

Tingkah Laku beristrirahat biasanya duduk atau berbaring tetapi tidak termasuk dalam aktifitas sosial termasuk auto grooming (Kinnard dan O'Brien ,1997 dalam Tasin ,2009). Tingkah laku beristirahat Tangkasi berbeda dengan tingkah laku beristirahat primata lain karena Tangkasi beristirahat dengan cara berdiam sambil berkumpul dengan proses yang saling berhimpitan tubuh mengecilkan bola matanya dan mengerutkan daun telinga tetapi kewaspadaan terhadap suara atau gerakangerakan yang muncul tetap dipertahankan. Hal ini terlihat saat peneliti mengambil gambar (foto), maka dengan kedua tangannya mereka langsung membuka mata, menggerak-gerak telinganya sambil mengubah posisi untuk berpindah tempat atau memasuki lubang sarang yang lebih dalam lagi,karena bentuk lubang pohon saling berlekuk.

Sebagai hewan nocturnal maka Tarsius akan menunjukan aktifitas makan yang terbatas disaat mempersiapkan diri untuk memasuki lubang sarang dan ini merupakan konsekuensi dari besarnya aktifitas perilaku yang dilakukannya di malam hari karena aktifitas disiang hari lebih banyak digunakan untuk beristirahat. Besarnya persentase tingkah laku beristierahat dapat dilihat pada Gambar 2.

Data di atas menunjukan bahwa tingkah laku beristirahat Tangkasi paling banyak terjadi saat siang hari yaitu $38,70 \%$. Hal tersebut sesuai dengan tingkah laku alami Tangkasi yang merupakan satwa nocturnal yang artinya beraktifitas pada malam hari. Sedangkan tingkah laku beristirahat Tangkasi pada pagi hari hanya $32,25 \%$, dan tingkah laku beristirahat Tangkasi paling sedikit di sore hari 29,03\%. Hal ini diduga karena 


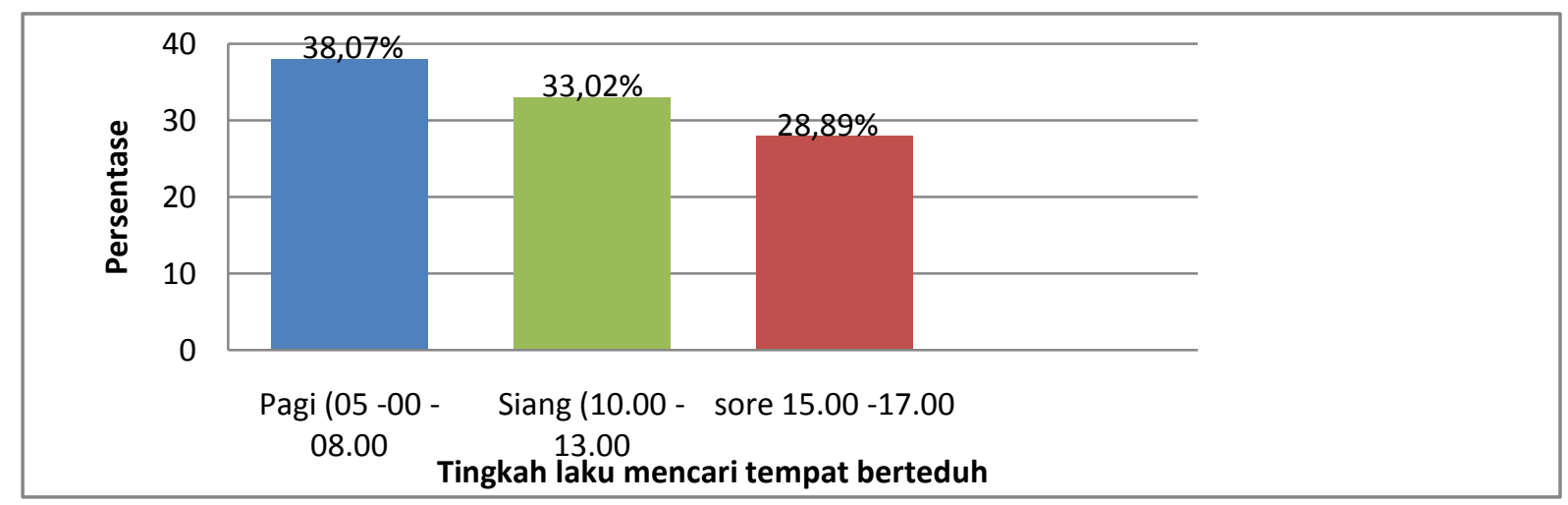

Gambar 3.Persentase tingkah laku mencari tempat Berteduh Tarsius spectrum

Tangkasi mulai bersiap untuk berburu makanan menjelang malam hari sehingga memperkecil aktifitas beristirahatnya.

\section{Tingkah Laku Mencari Tempat Berteduh (Shelter seeking).}

Tingkah laku mencari tempat berteduh merupakan salah satu tingkah laku alami satwa dalam mencari tempat untuk berteduh dan jauh dari serangan predator. Aktifitas mencari tempat berteduh Tangkasi biasanya dilakukan oleh Tangkasi jantan dewasa dan tingkah laku ini terjadi secara alami dimana Tangkasi jantan dewasa lebih dulu mencari tempat untuk berteduh sambil melihat situasi habitat sekitarnya, kemudian Tangkasi jantan memberi isyarat berupa suara lengkingan yang tajam dan panjang yang menandakan bahwa Tangkasi jantan sudah mendapatkan tempat untuk berteduh pada waktu beristirahat nanti.
Hasil pengamatan dilapangan menunjukan bahwa Tarsius sudah sangat mengenal lokasi lubang sarang pohon yang akan mereka diami secara berkelompok dan bila tidak ada gangguan maka Tarsius secara berkelompok akan menjadikan sarang lubang pohon sebagai home base mereka, artinya mereka telah memberi tanda dengan menggunakan kelenjar yang ada pada kedua lipitan paha yang disebut "epigastrik glands" tanda dengan bebauan bahwa lokasi terbuat aman untuk dijadikan tempat tinggal mereka.

Hal ini jelas disampaikan oleh Rowe et al (1996), bahwa Tarsius jantan maupun betina akan memberikan tanda yang berbau dengan menggunakan epigastric glands ( Kelenjar -kelenjar antara dua lipitan paha) sebagai penandaan disaat keluar meloncat pohon satu ke pohon yang lain dan akhirnya akan kembali lagi pada lokasi yang telah 


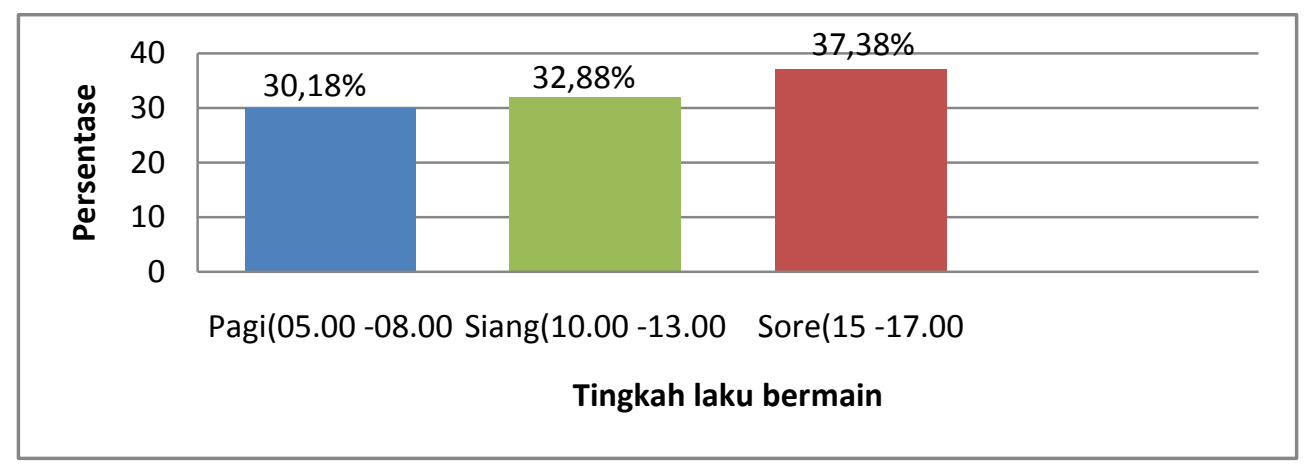

Gambar 4. Persentase tingkah laku bermain Tangkasi( Tarsius pectrum)

ditempatinya. Besarnya persentase tingkah laku mencari tempat berteduh dari Tarsius disaat memasuki lubang sarang pohon terlihat dari Gambar 3.

Data di atas menunjukan persentase Tingkah laku mencari tempat berteduh Tangkasi di Cagar Alam Tangkoko tidak terjadi secara terus menerus namun diduga karena adanya gangguan dari predator atau perubahan suhu habitat. Tingkah laku yang paling banyak terjadi di pagi hari setelah Tangkasi kembali dari berburu makanan adalah mencari tempat berteduh dimana besarnya tingkah laku ini adalah 38,07\% dan pada waktu siang 33,02\%. Hal ini diduga Tangkasi melakukan tingkah laku ini karena adanya desakan dari predator yang berada disekitar sarang mereka. Pada sore hari $28,89 \%$ diduga karena Tangkasi mencari tempat yang dekat dengan sumber makanan dan masih aman dari gangguan kebisingan atau predator, sehingga mempermudah dalam mencari makanan yang ada disekitar mereka.

\section{Tingkah Laku Bermain}

Tingkah laku bermain merupakan tingkah laku yang ditimbulkan satwa saat sedang beristirahat maupun saat sedang beraktifitas. Tingkah laku bermain termasuk dalam tingkah laku sosial karena Tingkah laku bermain terjadi antara 2 satwa atau lebih. Tingkah laku bermain Tangkasi biasanya terjadi saat sedang beristirahat dimana Tangkasi yang sedang beristirahat biasanya melakukan aktifitas berkelompok salah satunya adalah bermain.

Tangkasi berada dalam sarang umumnya lebih dari satu ekor dimana tingkah laku bermain yang ditimbulkan Tangkasi saat berada dalam sarang adalah saling kejar-kejaran antara jantan dewasa dengan betina dewasa, terkadang pola Tingkah laku bermain yang ditimbulkan adalah melompat dari ranting satu ke ranting lain di sekitar tempat yang didiami.

Hasil penelitian ini juga didapati 
pola tingkah laku bermain Tangkasi betina dewasa dimana Tangkasi betina dewasa menggigit anaknya sambil melompat. Hal ini diduga merupakan pola pembelajaran kepada anak. Tingkah laku bermain ini hanya berada dalam ruang lingkup dalam sarang dan ranting di sekitar sarang dan hal ini karena sensitifitas Tangkasi terhadap objek yang tidak dikenalnya. Semua tingkah laku ini jelas terlihat dari besarnya persentase tingkah laku bermain Tangkasi seperti pada Gambar 4.

Tangkasi melakukan tingkah laku bermain hampir merata setiap waktu. Pada waktu pagi Tangkasi bermain setelah selesai mencari makan dengan persentase $30,18 \%$ dan pada waktu siang Tangkasi bermain sambil beristirahat dengan persentase $32,88 \%$ dan paling banyak pada waktu sore Tangkasi bermain sebelum keluar mencari makan dengan persentase $37,38 \%$. Hal ini menunjukkan perilaku sosial Tangkasi sangat tinggi antar individu terlebih pada saat persiapan untuk melakukan perburuan di sore menjelang malam hari.

\section{KESIMPULAN}

Tingkah laku Tangkasi ( Tarsius spectrum) saat beraktifitas di sekitar sarang pohon di Cagar Alam Tangkoko terindikasi empat tingkah laku yaitu :
- Tingkah laku grooming Tangkasi yang lebih banyak dilakukan saat pagi hari $(37,19 \%)$.

- Tingkah laku beristirahat Tangkasi paling banyak terjadi pada waktu siang hari $(38,70 \%)$

- Tingkah laku mencari tempat berteduh Tangkasi dilakukan oleh jantan dewasa dengan mengeluarkan suara lengkingan yang tajam dan panjang. Tingkah laku ini biasanya dilakukan pada pagi hari ( 33,02 \%) saat akan kembali ke sarang.

- Tingkah laku bermain Tangkasi berupa kejar-kejaran, melompat, dan paling banyak dilakukan pada waktu sore hari $(37,38 \%)$ saat akan mencari makanan.

\section{DAFTAR PUSTAKA}

Alikodra, HS. 1990. Pengelolaan Satwa Liar. Volume Ke1.Departemen Pendidikan dan Kebudayaan Pusat Antar Universitas, Pusat Ilmu Hayati.

Amir, H. 1978. Mamalia di Indonesia, Pedoman Inventarisasi Satwa. Bogor: Direktorat Perlindungan dan Pengawetan Alam, Direktorat Jendral Kehutanan

Biley; J. A; 1984; Principles of Wildlife Management; Jhon 
Willey \& Sons, Inc; USA

Eudey, A.A. 1987. Action Plan For Asian

Primate Conservation. WWF. USA

Goodall, J. 1996. The Pictorial Guide to The Living Primates. Pongonias Press. New York.

Grizmek, C . 1972. Animal Life Encyclopedia. Van Nastran Rheihald Company

Gursky, S. 2005. Predator Mobbing in Tarsius spectrum International Journal of Primatology.Springer SeienceBusiness Media, LLC . 207 -221 pp.

Kinnaird, MF. 1997. Sulawesi Utara Sebuah Panduan Sejarah Alam. Volume Ke I. Jakarta: Yayasan Pengembangan Wallace, hlm 61-62).

Kiroh, HJ. 2002. Studi Tingkah Laku Makan( ingestive) dan Penagkaran Semi In Situ ( Laporan Penelitian ). Manado Universitas Sam Ratulagi, Fakultas Peternakan.

Hidinoto .1993. Studi Perilaku dan Populasi Monyet Ekor Panjang( macaca Facicularis RAFLES 1821) Dalam Kandang Penangkaran (Skripsi). Fakultas Kehutanan Institut Pertanian Bogor.

Mac Kinnon, J dan Kathy Mac Kinnon; 1980; The Behavior of
Wildlife Spectral

Tarsiers. International Journal of Primatology, Vol 1 No. 4

Niemitz, C., 1984. Biologi of Tarsier. Gustav Fischer Verlag. Stutgart.

Rowe, N.1996. The Pictorial Gudie To The Living Pinates Posonias Press. East Hamption Newyonk,Hlm 53-56

Shekelle, M dan Robert, W. Sussman. 1997. The Ecology Tarsiers. Departement of Anthropologhy

Washington University. USA.

Supriatna J., Hendra E. 2000. Panduan Lapangan Primata Indonesia.Yayasan Obor Indonesia.

Suratmo F.G., 1970. Prinip Dasar Tingkah Laku Satwa Liar.Institut Pertanian Bogor. Fakultas Kehutanan.

Sondart. E., 1966. Manajemen and Behavior of Breeding Gorup of the Marsupial Perameles nasuta geoffray In captivity Aust . J. Zool ,.14 b.11-23 